\title{
A NEW APPROACH TO PERFORMANCE ANALYSIS OF POINT-TO-POINT RADIO LINKS AT FREQUENCIES ABOVE $70 \mathrm{GHz}$
}

\author{
Miroslav V. Perić ${ }^{*}$ - Dragana B. Perić ${ }^{* *}$ \\ - Branislav M. Todorović ${ }^{* * *}$
}

\begin{abstract}
In this paper we discuss high throughput fixed point-to-point radio links in frequency bands above $70 \mathrm{GHz}$. These links are interesting as a commercial alternative to fiber connections in IP computer networks. Characteristics of equipment used for radio transmission above $70 \mathrm{GHz}$ are presented. As rain is being the predominant propagation effect that causes link outages, standard rain model is described. Performance analysis in the case of adaptive radio equipment is presented. A new approach to point-to-point radio link performance analysis, that uses two dimensional rain cell models and performance criterion based on end-user experience, is proposed. This approach is compared with the standard point-to-point radio link performance analysis procedure, based on calculation of percentage of time when link is unavailable and percentage of time when link has reduced capacity. It is shown on characteristic examples that proposed performance analysis gives better insight into how rain event would really affect end-user.
\end{abstract}

K e y w ords: radio transmission, microwaves, IP networks, frequencies above $70 \mathrm{GHz}$, rain, performance analysis

\section{INTRODUCTION}

Microwave radio transmission in frequency bands above $70 \mathrm{GHz}$ is suitable for realization of wide bandwidth communications. In recent years they are increasingly used by service providers and system designers [1]. Applications that are predominantly realized in these frequency bands are high throughput (1 Gbit/s and above) short hop (up to $10 \mathrm{~km}$ ) IP radio networks. Fixed pointto-point radio links may be deployed much quicker and in certain cases are more cost efficient than the wired networks. Licensing in these frequency bands is often in a "light licensing" regime, which means that license prices are much lower than in frequency bands below $38 \mathrm{GHz}$ [2], [3]. High directional/high gain antennas of relatively small size can be used; therefore interference is reduced what simplifies frequency planning [4]. Main drawback of point-to-point radio links in frequency bands above $18 \mathrm{GHz}$ is its susceptibility to rain, which can cause link outages [5]. This effect increases with frequency. At frequencies around $60 \mathrm{GHz}$, there is an additional effect where water and oxygen molecules resonate, which produces local maximum attenuation [6]. As a consequence, the hop length is dramatically reduced to $1-1.5 \mathrm{~km}$. At frequencies above $70 \mathrm{GHz}$, attenuation caused by oxygen and water absorption is smaller and the rain attenuation is the predominant limitation for hop length. According to current regulations [2], [3], [7], frequency bands 71-76 GHz and/or $81-86 \mathrm{GHz}$ are assigned to Fixed Services in Europe and USA. By using link performance evaluation model given in [8], for average European rain rates availability objectives $99.95 \%$, hop length $3-6 \mathrm{~km}$ could be achieved. For higher availability objectives, same hop lengths could be achieved by applying capacity reduction. Furthermore, additional improvements of complete IP network performances based on such point-to-point links could be improved by using backup routes calculated with algorithms suitable for this frequency band [9].

Single link performance, calculated by using standard procedures given in [5], [8] strongly depends on assumed local climate characteristics. In [10], climate zones and corresponding rain characteristics for wide geographic regions are presented; however on smaller areas local characteristics may significantly differ from these values. Also, results of these calculations are numbers denoting percentages of time of link unavailability and percentages of time when link has reduced capacity, but it is not clear how rain event would really affect end-user. Alternatively, using two dimensional rain cell models [11], [17-25], performance criterion based on end-user experience [26] can give better insight into consequences of rain event.

This paper is organized as follows. Section 2 presents main characteristics of microwave radio equipment at frequencies above $70 \mathrm{GHz}$, while in Section 3 standard performance analysis is presented. In Section 4, proposed approach to performace analysis is described, while in Section 5 numerical resuts are presented. Finally, in Section 6 main conclusions are given.

\footnotetext{
${ }^{*}$ P3 - Communications Engineering d.o.o., Sokobanjska 1a, 11000 Belgrade, Serbia, miroslav.peric@p3-group.com; ${ }^{* *}$ Institute of Microwave Techniques and Electronics, IMTEL Komunikacije a.d., Blvd. M. Pupin 165 B, 11070 Belgrade, Serbia, dragana@insimtel.com; *** RT-RK d.o.o., Institute for Computer Based Systems, Narodnog Fronta 23A, 21000 Novi Sad, Serbia, branislav.todorovic@rt-rk.com
} 


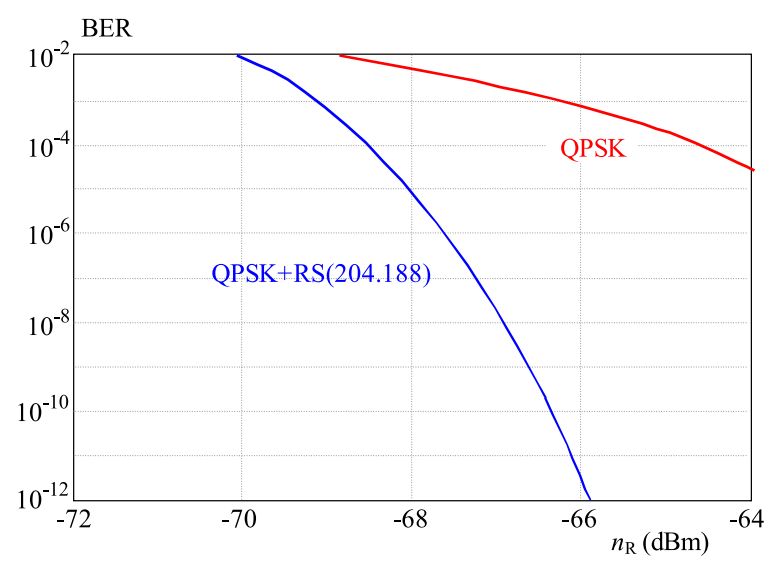

Fig. 1. Example of dependence of error probability from received signal level for $1 \mathrm{Gbit} / \mathrm{s}$ equipment with QPSK modulation: (a) - without error protection coding and (b) - with Reed-Solomon coding RS(204,188)

Table 1a. Typical receiver characteristics for $1 \mathrm{Gbit} / \mathrm{s}, 128 \mathrm{QAM}$ equipment operating in $250 \mathrm{MHz}$ channel bandwidth

\begin{tabular}{lcc}
\hline Frequency bands $(\mathrm{GHz})$ & 71 to 76 & 81 to 86 \\
Receiver noise bandwidth $(\mathrm{MHz})$ & 190 & 190 \\
Receiver noise figure @ Antenna port $(\mathrm{dB})$ & 12 & 13 \\
Receiver signal power for BER $10^{-6}(\mathrm{dBm})$ & -56 & -55 \\
\hline
\end{tabular}

Table 1b. Typical receiver characteristics for $1 \mathrm{Gbit} / \mathrm{s}, 16$ QAM equipment operating in a $500 \mathrm{MHz}$ channel bandwidth

\begin{tabular}{lcc}
\hline Frequency bands $(\mathrm{GHz})$ & 71 to 76 & 81 to 86 \\
Receiver noise bandwidth $(\mathrm{MHz})$ & 350 & 350 \\
Receiver noise figure @ Antenna port $(\mathrm{dB})$ & 12 & 13 \\
Receiver signal power for BER $10^{-6}(\mathrm{dBm})$ & -61 & -60 \\
\hline
\end{tabular}

Table 1c. Typical receiver characteristics for 1 Gbit/s, FSK equipment operating in a $1250 \mathrm{MHz}$ channel bandwidth

\begin{tabular}{lcc}
\hline Frequency bands $(\mathrm{GHz})$ & 71 to 76 & 81 to 86 \\
Receiver noise bandwidth $(\mathrm{MHz})$ & 100 & 100 \\
Receiver noise figure @ Antenna port $(\mathrm{dB})$ & 12 & 13 \\
Receiver signal power for BER $10^{-6}(\mathrm{dBm})$ & -64 & -63 \\
\hline
\end{tabular}

\section{RADIO EQUIPMENT ABOVE $70 \mathrm{GHZ}$}

Microwave radio equipment characteristics are recommended by European regulatory bodies. ECC/REC (05)07 defines the channel arrangement for the $71 \mathrm{GHz}$ to $76 \mathrm{GHz}$ and $81 \mathrm{GHz}$ to $86 \mathrm{GHz}$ bands [7]. Within each $5 \mathrm{GHz}$ bandwidth, nineteen $250 \mathrm{MHz}$ channels are defined, with a $125 \mathrm{MHz}$ guard band at the bottom and top of each $5 \mathrm{GHz}$ band. Aggregation of any number of channels, from 1 to 19 , is permitted which enables usage of larger variety of modulation schemes [12]. Typical receiver characteristics for $71 \mathrm{GHz}$ to $76 \mathrm{GHz}$ and $81 \mathrm{GHz}$ to $86 \mathrm{GHz}$ equipment are given in Tabs. 1.a, b and c [13].

Receiver threshold $n_{R T}(B E R)$ represents minimum received signal level for bit error ratio (BER) lower than specified value. This dependence could be described as $[12]$

$n_{R T}(B E R)=10 \log k T+10 \log B_{R F}+F+E_{b} / N_{0}(B E R)$

where $k=1.38 \times 10^{-23}\left(\left(\mathrm{~m}^{2} \mathrm{~kg} / \mathrm{s}^{2} / K\right)\right.$ is the Boltzman constant, $T$ absolute temperature $(\mathrm{K}), B_{R F}$ signal frequency bandwidth $(\mathrm{Hz}), F$ noise figure $(\mathrm{dB})$ and $E_{b} / N_{0}(B E R)$ is the ratio of minimum energy per bit $E_{b}$ and noise spectral power density $N_{0}$ for bit error rate lower than specified value.

In the case of point-to-point radio links above $70 \mathrm{GHz}$, receiver thresholds for $1 \mathrm{Gbit} / \mathrm{s}$ are high, even for robust modulations and codes applied. For example, for BPSK or DBPSK radio units with Reed Solomon coding, receiver threshold is typically $60 \mathrm{dBm}[12]$, [14].

Difference between received signal level in absence of fading $n_{R 0}$ and receiver threshold is called fading margin $a_{F M}(\mathrm{~dB})$ :

$$
a_{F M}(B E R)=n_{R O}-n_{R T}(B E R) .
$$

Greater value of fading margin guarantees better resistance to propagation conditions. Typically, fading margins are in the range 15 to $50 \mathrm{~dB}$ [4], [8]. Calculation of $n_{R 0}$ is described in [8].

Receiver threshold depends on signal bandwidth $B_{R F}$ that is directly proportional to signal throughput, ie link capacity as

$$
B_{R F}=m C
$$

where $m$ is spectral efficacy of modulation method given in (bit/Hz). By reducing link capacity, receiver threshold decreases and fading margin becomes greater.

Typical dependence of bit error ratio versus receiver signal level is shown in Fig. 1. Calculation is done for: $B_{R F}=1.4 \mathrm{GHz}, F=10 \mathrm{~dB}$, room temperature, QPSK modulation is applied: (a) without error protection coding and (b) with Reed-Solomon code RS $(204,188)$.

In systems for packet radio transmission, as IP systems, it is possible to improve receiver threshold and therefore fading margin, while data are transmitted. Such system is adaptive to propagation conditions. Common names for these systems are systems with adaptive throughput, modulation and/or coding. Criterion for switching from one working mode to another can be either received signal level or interference level [12]. Adaptive systems are usually implemented by using hysteresis in order to avoid instability. Possible packet loss during transmission is minimized by using buffers of adequate size. Congestion of these buffers is out of scope of this paper.

Point-to-point radio link capacity can be expressed as a function of received signal level [12]. Link can be 
Table 2. Characteristics link A with hop length $3 \mathrm{~km}$ and antenna diameter $0.3 \mathrm{~m}$

\begin{tabular}{cccc}
\hline$P_{T x}$ & & $17 \mathrm{dBm}$ \\
$G_{a}+G_{b}$ & & $8 \mathrm{dBi}$ & \\
$n_{R T}(1 \mathrm{Gbit} / \mathrm{s})$ & & $-65 \mathrm{dBm}$ & \\
$n_{R T}(100 M \mathrm{bit} / \mathrm{s})$ & & $-75 \mathrm{dBm}$ & \\
$n_{R T}(10 \mathrm{Mbit} / \mathrm{s})$ & & $-85 \mathrm{dBm}$ & \\
$n_{F M}(1 \mathrm{~Gb} / \mathrm{s})$ & & $27.8 \mathrm{~dB}$ & \\
$n_{F M}(100 \mathrm{Mbit} / \mathrm{s})$ & & $37.8 \mathrm{~dB}$ & \\
$n_{F M}(10 \mathrm{Mbit} / \mathrm{s})$ & & $47.8 \mathrm{~dB}$ & \\
$R_{0.01 \%}(\mathrm{~mm} / \mathrm{h})$ & 30 & 42 & 60 \\
$t_{\text {Gbit } / \mathrm{s}}(\%)$ & 99.9829 & 99.9660 & 99.9322 \\
$t_{100 \mathrm{Mbit} / \mathrm{s}}(\%)$ & 0.0099 & 0.0201 & 0.0406 \\
$t_{10 \mathrm{Mbit} / \mathrm{s}}(\%)$ & 0.0032 & 0.0066 & 0.0134 \\
$t_{\text {unavailable }}(\%)$ & 0.0039 & 0.0072 & 0.0137 \\
\hline
\end{tabular}

Table 3. Characteristics link B with hop length $6 \mathrm{~km}$ and antenna diameter $0.6 \mathrm{~m}$

\begin{tabular}{cccc}
\hline$P_{T x}$ & $17 \mathrm{dBm}$ & \\
$G_{a}+G_{b}$ & & $102 \mathrm{dBi}$ & \\
$n_{R T}(1 \mathrm{Gbit} / \mathrm{s})$ & & $-65 \mathrm{dBm}$ & \\
$n_{R T}(100 M \mathrm{bit} / \mathrm{s})$ & & $-75 \mathrm{dBm}$ & \\
$n_{R T}(10 \mathrm{Mbit} / \mathrm{s})$ & & $-85 \mathrm{dBm}$ & \\
$n_{F M}(1 \mathrm{~Gb} / \mathrm{s})$ & & $34.6 \mathrm{~dB}$ & \\
$n_{F M}(100 \mathrm{Mbit} / \mathrm{s})$ & & $44.6 \mathrm{~dB}$ & \\
$n_{F M}(10 \mathrm{Mbit} / \mathrm{s})$ & & $54.6 \mathrm{~dB}$ & \\
$R_{0.01 \%}(\mathrm{~mm} / \mathrm{h})$ & 30 & 42 & 60 \\
$t_{\text {Gbit/s }}(\%)$ & 99.9502 & 99.9048 & 99.8253 \\
$t_{100 \mathrm{Mbit} / \mathrm{s}}(\%)$ & 0.0266 & 0.0510 & 0.0936 \\
$t_{10 \mathrm{Mbit} / \mathrm{s}}(\%)$ & 0.0103 & 0.0199 & 0.0368 \\
$t_{\text {unavailable }}(\%)$ & 0.0129 & 0.0243 & 0.0442 \\
\hline
\end{tabular}

in down state, when data are not transmitted due to excess attenuation, and link capacity equals zero. Due to very steep dependence BER of $n_{R}$ in radio equipment, that is consequence of modern error protection coding methods, it can be considered that when link is in up state, transmission is errorless and capacity depends only on receiver threshold

$$
C=C\left(n_{R}\right)
$$

For analyzing impact of fading caused by rain in radio network, by using equation (2) it is convenient to transform this expression into dependence of radio link capacity from fading attenuation

$$
C=C\left(a_{F}\right)
$$

\section{STANDARD PERFORMANCE ANALYSIS}

According to standard radio link planning procedure [4], [8] percentage of time of link unavailability is determined when fading attenuation is greater than fading margin $\left(a_{F}>a_{F M}\right)$. For links with adaptive modulation due to capacity change, we distinguish: percentage of time in which link works with full capacity, percentage of time in which link works with reduced capacity and percentage of time when link is unavailable.

We describe rain model used in standard performance analysis and present numerical results for two types of radio links with assumed rain characteristics.

\subsection{Standard rain model}

In [5], [8] equation for calculation of specific attenuation caused by rain $\gamma_{R}(\mathrm{~dB} / \mathrm{km})$ is given by

$$
\gamma_{R}=K R^{\alpha}
$$

where $R$ is rain intensity, while $K$ and $\alpha$ are factors which depend on frequency and polarization.

Overall attenuation calculated for one hop is integral equation with specific attenuation as a parameter. For this calculation, values of specific attenuation are needed along the entire hop

$$
A_{R}=\int_{0}^{R} K R(l)^{\alpha} \mathrm{d} l,
$$

where $R(l)$ is function of rain intensity along the link path. In order to calculate percentage when rain attenuation exceeds fading margin the cumulative distribution function of rain intensity should be known, which has very local geographical character and requires long term meteorological measurements. Therefore, approximation for calculation of unavailability time percentage caused by rain is suggested [5], [8]. This approximation is based on single value of cumulative distribution function for $0.01 \%$ of time, $R_{0.01 \%}$. The approximate values for $R_{0.01 \%}$ could be found in [10], while more accurate values could be obtained from local meteorological institutions.

\subsection{Standard performance analysis criterion}

Concept of adaptive radio equipment demands different approach to system performances calculation. Equipment manufacturers recommend calculation of time percentage in which system has demanded capacity and percentage of time when link is unavailable. Example of this calculation is given in Table 2. for Link A (point-to-point radio link with hop length $L=3 \mathrm{~km}$ and antenna diameter $0.3 \mathrm{~m}$ ) and in Table 3. for Link B (point-to-point link with hop length $L=6 \mathrm{~km}$ and antenna diameter $0.6 \mathrm{~m}$ ). Equipment parameters such as transmitter power $p_{T x}$, gains of antenna $G_{a}$ and $G_{b}$, and receiver threshold $n_{R T}$ as a function of link capacity for quasi-error-free transmission are taken in accordance with standards [11]. 


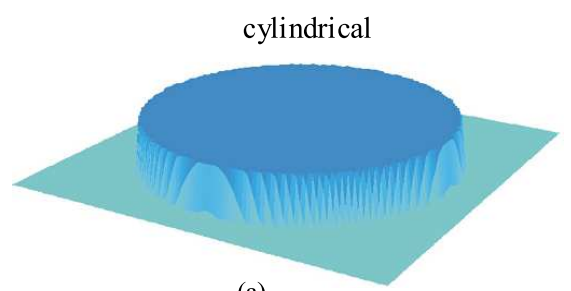

(a)

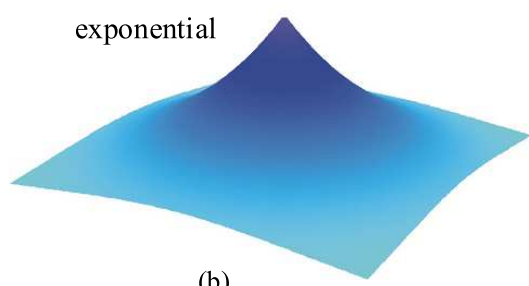

(b)

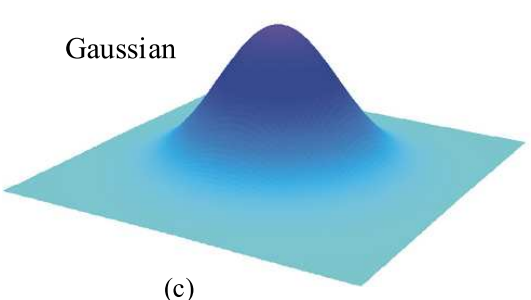

(c)

Fig. 2. Two dimensional structures of various types of rain cells: (a) - stratiform rain - cylindrical model, (b) - convective rain exponential model, (c) - stratiform rain - Gaussian model

\subsection{Numerical results}

Using propagation model defined in recommendation ITU-R P.530-13 [8] and assuming central frequencies $80 \mathrm{GHz}$ with vertical polarization, time percentages are calculated $t_{1 \mathrm{Gbit} / \mathrm{s}}, t_{100 \mathrm{Mbit} / \mathrm{s}}$ and $t_{10 \mathrm{Mbit} / \mathrm{s}}$ when link has capacity of $1 \mathrm{Gbit} / \mathrm{s}, 100 \mathrm{Mbit} / \mathrm{s}$ and $10 \mathrm{Mbit} / \mathrm{s}$ respectively. With given conditions, fading margins that match these links are $n_{F M}(1 \mathrm{Gbit} / \mathrm{s}), n_{F M}(100 \mathrm{Mbit} / \mathrm{s})$ and $n_{F M}(10 \mathrm{Mbit} / \mathrm{s})$. Calculations are done for characteristic values of rain intensities exceeded in $0.01 \%$ time, ranging from 30,42 and $60 \mathrm{~mm} / \mathrm{h}$, that result in specific rain attenuations of $12.3,16.0$ and $21.0 \mathrm{~dB} / \mathrm{km}$, respectively.

Described standard point-to-point radio link performance analysis [5], [8], whose results are presented in Table 2. and Table 3., has following drawbacks:

- strong dependence on assumed local rain parameters, and

- uncertainty of how rain event would really affect enduser.

\section{DESCRIPTION OF THE PROPOSED APPROACH TO PERFORMANCE ANALYSIS}

We propose point-to-point radio link performance analysis based on two dimensional rain cell models [11], [17-25] and performance criterion based on end-user experience similar to that in definition of key performance indicator (KPI) in mobile networks [26].

\subsection{Two dimensional rain cell models}

Research based on measurements of gauges, radar images and/or satellite images allowed rain model definition. It has been shown that rain appears in form of rain cell, characterized by spatial rain intensity distribution [11].

In the technical literature there are two types of rain cells: stratiform and convective. Stratiform rain cell has relatively low rain intensity (up to $20 \mathrm{~mm} / \mathrm{h}$ ), it is uniformly distributed in space and has relatively large diameter (over $5 \mathrm{~km}$ ). Taking these values into account and values of typical fading margins in frequency bands above $70 \mathrm{GHz}$, it can be concluded that for most pointto-point radio links such rain cell doesn't degrade link performance. Another rain cell type is convective, with heavy rain intensity in rain cell centre which decreases towards periphery. Research has shown that maximum rain intensity and rain cell diameter are inversely correlated [17], [18]. Distances between larger numbers of rain cells are greater than $10 \mathrm{~km} \mathrm{[19],} \mathrm{[20],} \mathrm{therefore} \mathrm{in} \mathrm{analysis}$ of efficacy of traffic protection in networks above $70 \mathrm{GHz}$ only one cell's influence can be assumed.

There are many rain intensity models for rain cells, eg EXCELL-exponential [11], HYCELL-ellipsoidal Gauss [21] and Gauss [22]. For performance evaluation of pointto-point radio networks above $70 \mathrm{GHz}$, Gauss model is defined by expression

$$
R(d)=R_{\max } \exp \left[-0.5(3 d / 0.8 \rho)^{2}\right], d<\rho
$$

where $d$ denotes distance from the center of the rain cell, $R_{\max }$ denotes maximum rain intensity (in rain center), and $\rho$ denotes rain cell diameter.

In Fig. 2 rain intensity distribution function are displayed for different types of rain cells available in the literature: cylindrical distribution for stratiform rain cell and exponential and Gauss distribution for convective rain cell.

Rain cell is carried in space by wind. For different geographic areas, different wind speeds and different probabilities of its direction are presented [18], [19]. In our research rain cell speed of $10 \mathrm{~m} / \mathrm{s}$ is assumed, while direction and starting position are changeable.

In summary, model of radio link above $70 \mathrm{GHz}$ is defined by link capacity in given moment which is a function of fading margin on that link and rain cell parameters: rain cell center coordinates, $R_{\max }(\mathrm{mm} / \mathrm{h})$ and $\rho(\mathrm{km})$. Rain attenuation model is compared with actual measured attenuation for some specific geographic area in [23-25].

\subsection{Definition of new performance analysis crite- rion}

Let us denote point-to-point radio link capacity change in time with $c(t)$. This capacity change is a result of adaptive modulation mechanism that reacts after rain attenuation changes. Criterion for proposed point-to-point radio link performance analysis is defined as a function 


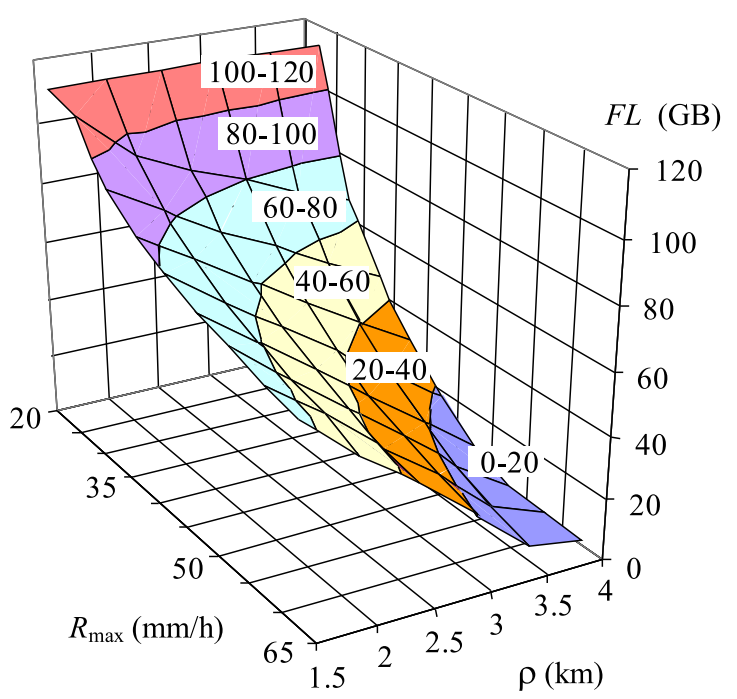

Fig. 3. Dependence of $F L_{\min }(v=10 \mathrm{~m} / \mathrm{s})$ of $R_{\max }$ and $\rho$ for Link A

of rain cell parameters. Point-to-point radio link performance criterion, denoted with $F L$, represents the total amount of transmitted data during the rain interval $T k$.

$$
F L\left(R_{\max }, \rho, v, p\right)=\int_{0}^{Y_{k}} c(t) \mathrm{d} t .
$$

Value of $F L$ depends not only on rain cell parameters $R_{\max }$ and $\rho$, but also on initial rain cell position $p$ and rain cell speed $v$. Taking into account the assumed Gaussian distribution of rain intensity in a rain cell, it is obvious that minimal value of $F L$ is obtained when rain cell center is close to the centre of the hop during observation period, which is

$$
p \in\{L / 2-v T k / 2, L / 2+v T k / 2\}
$$

where $L$ is hop length.

\section{NUMERICAL RESULTS}

In numerical calculations rain cell speed of $v=10 \mathrm{~m} / \mathrm{s}$ has been assumed. Calculated value of $F L$ under this assumption is denoted as $F L_{\min }(v=10 \mathrm{~m} / \mathrm{s})$. For different parameters $R_{\max }$ and $\rho$ value of $F L_{\min }(v=10 \mathrm{~m} / \mathrm{s})$ is calculated for point-to-point radio link Link A (Table 2) and Link B (Table 3). Results are shown on Figs. 3 and 4.

For characteristics given in Tables 2 and 3 it was calculated that Link B performance would be three times worse than Link B, since this is the ratio of time percentages when link operates at lower than nominal capacity. On the other hand, analysis of moving rain cell shows that such behavior could be expected only during high intensities $R_{\max }$, which occurs only on small geographical areas (small values for $R_{\max }$ ) during summer rain storms.

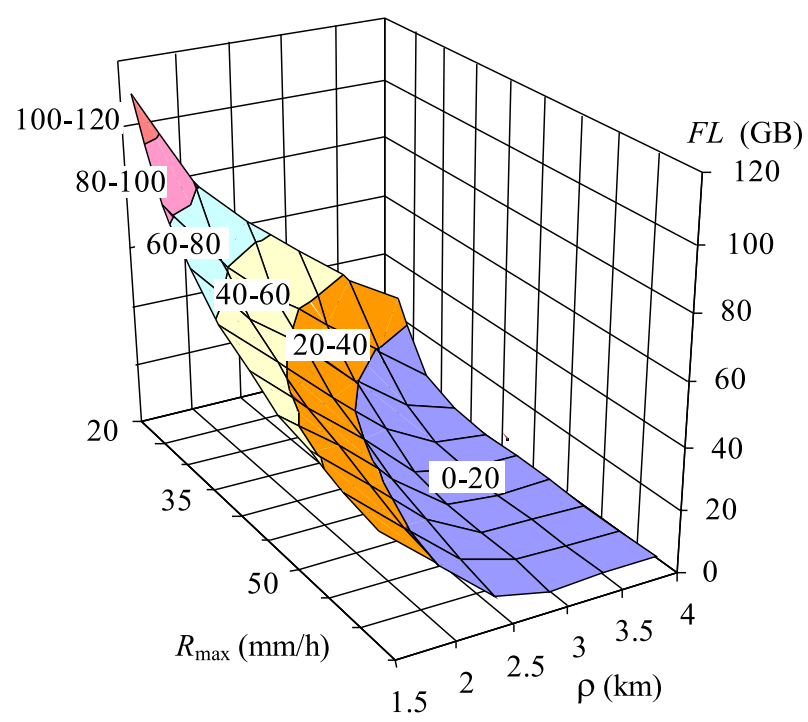

Fig. 4. Dependence of $F L_{\min }(v=10 \mathrm{~m} / \mathrm{s})$ of $R_{\max }$ and $\rho$ for Link B

This analysis shows that Link A user wouldn't experience any degradation of performances during majority of rain events, while Link B user would experience performance degradation frequently. This conclusion is not easily obtained from calculation results presenting percentage of time of link unavailability and percentage of time when link has reduced capacity.

\section{CONCLUSION}

Characteristics of microwave radio transmission in frequency bands above $70 \mathrm{GHz}$ are discussed. High throughput point-to-point radio links are analyzed in the case when adaptive radio equipment is used. A new approach to point-to-point radio link performance analysis, that uses two dimensional rain cell models and performance criterion based on end-user experience, is proposed. Standard point-to-point radio link performance analysis procedure is compared with proposed performance analysis. The main advantage of the proposed method is that it gives indication whether link performance would be acceptable to the end-user without precise knowledge of rain statistics, which usually is not available. In other words, it gives better insight into consequences of rain event. Proposed approach for performance analysis could be used in addition to standard outage time percentage analysis.

\section{Acknowledgement}

This work is supported by the Ministry of Education and Science of the Republic Serbia under Grants TR32052 and TR-36029.

\section{REFERENCES}

[1] WELLS, J.: Multigigabit Wireless Technology at $70 \mathrm{GHz}$, $80 \mathrm{GHz}$ and $90 \mathrm{GHz}, \mathrm{RF}$ Design (May 2006), 50-58. 
[2] www.ofcom.com.

[3] www.fcc.gov.

[4] Terrestrial Microwave Communications (Ivanek, F., ed.), Artech House, 1989.

[5] CRANE, R. K.: Prediction of Attenuation by Rain, IEEE Transactions on Communications COM-28 No. 9 (Sep 1980).

[6] Rec. ITU-R P.676-5, "Attenuation by Atmospheric Gases", 1990-2001.

[7] ECC REC. (05)07, Radio Frequency Channel Arrangements for Fixed Service System Operating in the bands $71-76 \mathrm{GHz}$ and 81-86 GHz, Edition February 2009.

[8] ITU-R Rec. P.530-13, "Propagation Data and Prediction Methods Required for Design of Terrestrial Line of Sight Systems", 10/2009.

[9] PERIĆ, D.-PERIĆ, M.-TODOROVIĆ, B. : Traffic Protection Method in IP Radio Networks above $70 \mathrm{GHz}$, IEEE Communications Letters 14 No. 10 (Oct 2010), 981-983.

[10] Rec. ITU-R P.837-4, "Characteristics of Precipitation for Propagation Modeling", 2003.

[11] BONATI, A. P.: Essential Knowledge of Rain Structure For Radio Application Based on Available Data and Models, Radio Africa 99 (Oct 1999).

[12] XIONG, F.: Digital Modulation Techniques, Artech House, 2000.

[13] ETSI TS 102524 V1.1.1 (2006-07), Radio Equipment and Antennas for Use in Point-to-Point Millimeter Wave Applications in Fixed Services Frequency Bands $71 \mathrm{GHz}$ to $76 \mathrm{GHz}$ and $81 \mathrm{GHz}$ to $86 \mathrm{GHz}, 2007$.

[14] LIN, S.-COSTELO, D. : Error Control Coding, Prentice Hall, 1983.

[15] ETSI EN 300 421, "Digital Video Broadcasting (DVB); Framing Structure, Channel Coding and Modulation for $11 / 12 \mathrm{GHz}$ Satellite Services V1.1.2 (1997-08)", European Telecommunications Standards Institute, 1997 ITU-R rec. P.838-3, "Specific Attenuation Model for Rain for Use in Prediction Methods", 2005.

[16] MATRICCIANI, E.-PAWLINA, A. : Statistical Characterization of Rainfall Structure and Occurrence for Convective and Stratiform Rain Inferred from Long Term Point Rain Rate Data, AP 2000 Millennium Conference on Antennas \& Propagation, Davos, Switzerland, 9-14 April 2000.

[17] ENJAMIO, C.-VILAR, E.-FONTAN, F. P.-REDANO, A.-NDZI, D.: Dimensions and Dynamic Evolution of Microscale Rain Cells, $2^{\text {nd }}$ International Workshop ES TEL, Noordwijk, The Netherlands, May 26-28 2003.

[18] ABDOU, A.-LEBEL, T.-AMANI, A. : Invariance in the Spatial Structure of Sahelian Rain Fields at Climatological Scales, Journal of Hydrometeorology 4 (Dec 2003), American Meteorological Society.

[19] FORERO, C. A. V.-SEED, A.-SEMPERE-TORRES, D.PEGRAM, G. : Optimal Estimation Of Rainfall Fields Merging Radar and Rain Gauges Data in an Operational Context, ERAD 2008, The Fifth European Conference on Radar in Meteorology and Hydrology, Helsinki, 2008.

[20] FERAL, L.-LEMORTON. J.-LAURENT, C.-SAUVAGEOT, H. : Hycell: A New Model of Rain Fields and Rain Cells Structure, Radio Science 38, 1056 (2003).

[21] SINKA, C.-LAKATOS, B.-BITO, J. : The Effects of Moving Rain Cell over LMDS Systems, COST A280, $1^{\text {st }}$ International Workshop, July 2002.

[22] MAYER, W.: Comparison of Fade Models form LMDS, IEEE 802.16cc-99.

[23] FELDHAKE, G. S.-SENGERS, A.: Comparison of Multiple Rain Attenuation Models with Three Years of Ka Band Propagation Data Concurrently Taken at Eight Different Locations, www.spacejournal.org No. 2 (Fall 2002).
[24] CHEFFEnA, M.-BRÅTENL. E.-EKMAN, T.: On the Space-Time Variations of Rain Attenuation, IEEE Transactions on Antennas and Propagation 57 No. 6 (June 2009).

[25] HIRATA, A.-TAKAHASHI, H.-KOSUGI, T.-MURATA, K.-NAOYA, K.-KADO, Y.: Rain Attenuation Statistics for a 120-GHz-Band Wireless Link, International Microwave Symposium Digest, Boston, June 2009, pp. 933-936.

[26] ETSI TS 132450 V9.1.0 (2010-07), Key Performance Indicators (KPI) for Evolved Universal Terrestrial Radio Access Network (E-UTRAN): Definitions, European Telecommunication Standards Institute, 2010.

Received 26 April 2011

Miroslav V. Perić received Diploma Engineer degree in 1993 and MSc degree in 2004, both from the Faculty of Electrical Engineering, University of Belgrade. Since 1993 he has been employed at Institute of Microwave Techniques and Electronics IMTEL Komunikacije a.d., Belgrade. In 2010 he joined P3 Communication Engineering, Belgrade. His research interests fall in the area of radio propagation, radio networks performance measurement and engineering and design of communications systems and measuring equipment. He is a member of IEEE and Serbian Engineering Chamber. For his work, he received Tesla prize in 2006 .

Dragana B. Perić received $\mathrm{PhD}$ degree from Faculty of Technical Sciences, University of Novi Sad, Serbia, in 2011. Prior to her doctoral degree, Dr Perić earned Diploma Engineer degree in 1993 and MSc degree in 2002, both from the Faculty of Electrical Engineering, University of Belgrade. Since 1993 she has been employed at Institute of Microwave Techniques and Electronics IMTEL Komunikacije a.d., Belgrade. Her research interests fall in the area of radio propagation, communication network planning, computer networks performance analysis and multiplexing equipment design for digital radio-relay links. In 2006 she became Head of Communication Systems Group at IMTEL Komunikacije a.d., Belgrade. She is a member of IEEE and Serbian Engineering Chamber.

Branislav M. Todorović received PhD degree from the Faculty of Faculty of Technical Sciences, University of Novi Sad, Serbia, in 1997. Prior his doctoral degree, Dr Todorović earned Diploma Engineer degree in electronics and MSc degree in telecommunications, both from the Faculty of Electrical Engineering, University of Belgrade. He does research in the various areas of telecommunications, informatics and applied physics. He has published over 80 peer-rewieved journal and conference articles, two books and a number of research reports. Prior to joining RT-RK d.o.o., Institute for Computer Based Systems, where he is Senior Research Fellow, he founded the Center for Multidisciplinary Research, spent three years with the Institute of Microwave Techniques and Electronics IMTEL Komunikacije a.d. and almost twenty years with the Military Technical Institute (formerly VTI, Institute of Electrical Engineering) in Belgrade. Besides research activities, he has taught a number of courses (radio communication systems, radio-relay and satellite systems, spread spectrum systems and military communications) at Military Academy, University of Defense, Belgrade, where he is part-time Associate Professor. Also, he teaches principles of communications at the Faculty of Electrical Engineering, University of Banja Luka, Bosnia and Herzegovina. Dr Todorović is Member of IEEE and Fellow of IoN. 